\title{
Global Emergencies: How Do They Affect Supply Chain Management Students?
}

\author{
Alexander Stratton, Sime Curkovic \\ Haworth College of Business, Center for Integrated Supply Management, Western Michigan University, Kalamazoo, Michigan, \\ USA
}

Email: alex.b.stratton@wmich.edu,sime.curkovic@wmich.edu

How to cite this paper: Stratton, A., \& Curkovic, S. (2021). Global Emergencies: How Do They Affect Supply Chain Management Students? Creative Education, 12, 231-264.

https://doi.org/10.4236/ce.2021.121018

Received: December 23, 2020

Accepted: January 26, 2021

Published: January 29, 2021

Copyright (c) 2021 by author(s) and Scientific Research Publishing Inc. This work is licensed under the Creative Commons Attribution International License (CC BY 4.0).

http://creativecommons.org/licenses/by/4.0/

\begin{abstract}
The aim of this research is to discover how the effects of global emergencies such as Covid-19 affect graduating supply chain management students. Global emergencies cause issues and can completely disrupt supply chains. It is hypothesized that since supply chain students may be of help in aiding these supply chains that they may currently or eventually be of higher need and value. Global disasters are full of uncertainties and it is unknown how an event on the scale of Covid-19 will influence employment decisions made by supply chain employers. Uncertainty can be worrisome and cause stress, so it is the goal of this project to remove some of those unknown and anxiety surrounding finding employment and to also figure out what employers are looking for in students during these critical times.
\end{abstract}

\section{Keywords}

Supply Chain Management, Global Disasters, Covid-19, Employers, Students

\section{Introduction}

Global emergencies can take a significant toll on the world in many ways. For example, the Covid-19 pandemic has taken its toll by shutting down millions of businesses for long periods of time, putting around 100,000 companies out of business for good within the first month of the outbreak in America (Long, 2020), and putting around 40 million U.S. employees out of work by the third month of the outbreak (Morath, 2020). This caused a lack of workforce and flow of goods, which in turn placed a high amount of stress on local and global supply chains.

Supply chain managers become very important to help organize, strategize, and improve upon a company's supply chain after a global emergency occurs, 
but it is uncertain how the dramatic effects of a global emergency will affect the job market and field of supply chain management for newly graduated students with minimal experience. Therefore, it is the aim of this research thesis project to investigate disruptions along supply chains due to global emergencies like Covid-19 and discover if they have had a beneficial or negative effect on the need for Integrated Supply Management students. If the effect proves to be beneficial, it is important to use this information to promote the Supply Chain Management field and help students better pitch themselves towards employers during times of emergency and distress.

\section{Background}

A survey conducted by Resilinc that reviewed the initial effects of the Covid-19 pandemic found that $70 \%$ of the 300 businesses who participated were unprepared along their supply chains (Choi, Vakil, \& Rogers, 2020). Data like this has alerted researchers to investigate the subject of emergencies and their effect on supply chain management. In, an article by Harvard Business Review they found that the Coronavirus outbreak should be a "wake-up call for supply chain management". The article outlined how supply network mapping is missing in many companies and how supply chain disruption is often overlooked when evaluating suppliers (Choi, Vakil, \& Rogers, 2020). These issues in supply chains brought about by Covid-19 must be addressed and should also be studied by students, so they may be prepared to help implement fixes in areas of their future employment.

Covid-19 has been one of the largest global emergencies in modern history, but it has not been the first. Past disasters such as, Chernobyl, the Fukushima Tsunami, and Hurricane Katrina have affected the world on a large scale as well (Kumar, 2011). In fact, many of the same faults along supply chains due to Covid-19 were also seen in those past disasters. Companies are now having to learn their lesson again after regretfully not fixing those faults (Linton \& Vakil, 2020). Therefore, this "wake up call" or realization that many supply chain segments are not resilient enough for emergencies should raise awareness for the need of a supply chain that is prepared for the future. In turn, this may benefit the field and job market for supply chain management individuals, because of their ability to improve a company's supply chain, by increasing performance, saving money, and adding another layer of efficiency to many other segments throughout the company (Pratt, 2013). This means that supply chain students may be of higher demand as they graduate and move onto their professional careers. The idea that global emergencies could possibly benefit the supply chain field and increase demand for supply chain students was the main driver of this research.

\section{Research Methodology}

The data for this project was gathered by sending out an anonymous link to a survey on the Qualtrics platform. The survey consisted of thirteen questions di- 
rected towards Supply Chain Management workers and employers. The survey included ranking, yes/no, and open-ended questions. Each of the respondents was sourced from Western Michigan University Alumni of the ISM Program now working in supply chain management positions. Of the 200 surveys sent out 121 took part in the survey, providing a $60.5 \%$ response rate to the survey. All the questions were formatted to maintain anonymity of the participants when answering. Each employer who participated in the survey did so voluntarily. The survey took place over a month's period (October 2020). Throughout the duration of this study while the survey was open there were no major changes in the Covid-19 pandemic situation, so the survey was successfully able to gather information from employers during the same period of the pandemic while facing similar challenges.

\section{Survey Content}

The survey was created to find how global emergencies affect the field of supply chain management for newly graduated students with minimal experience. Is the field better because of the need to rebuild and reform supply chains and because it can be a great learning experience for new hires or has this hurt the hiring rate for supply chain students as highly experienced supply chain managers are primarily needed during these stressful times? To answer this question the survey was sent to a wide variety of employers from many different industries. The survey asked questions referring to periods before and during Covid-19. The content included questions surrounding these subjects in the supply chain field:

- Covid-19 effects,

- Supply chain segments most affected,

- Industry changes,

- Hiring rates,

- What level of expertise recruiters are looking for (New talent or experienced individuals)?

- Necessary skills and attributes of graduating students.

a. Should students be trained on the implications of Covid-19?

b. What would help a graduating student stand out?

-Please refer to Appendix A to view the full survey that was completed by the supply chain employers.

-Please refer to Appendix $B$ to view the full responses to the open-ended questions that were completed by the employers.

\section{Data Analysis}

\subsection{Sample Size}

This study included a sample size of 121 participants. The size varies per question between 104 - 121 responses since not all questions were applicable to each participant. It was essential to have a large number of participants that included employers and supply chain workers from a wide variety of industries and com- 
panies. Employers from a wide variety of industries were used rather than employers from a specific industry so that overall data on how the field of supply chain management was affected by Covid-19 could be gathered. Also so that the data would more closely approximate the supply chain industry/population.

\subsection{Covid-19's Effects on the Supply Chain}

Figure 1 and Figure 2 summarize how many employers in the supply chain field feel their company's supply chain was affected by Covid-19 and how strongly they believe global emergencies in general affect supply chain management.

The data in Figure 1 \& Figure 2 shows that over 99\% agree and less than 1\% disagree with the idea that Covid-19 and global emergencies affect supply chain management. This indicates that most employers do in fact believe that Covid-19 and global emergencies have a significant effect on supply chains across multiple industries. This is important information as it means that due to the significance of global emergencies on supply chain management there is more

Employers Who Believe Covid-19 Has Affected their Supply Chain

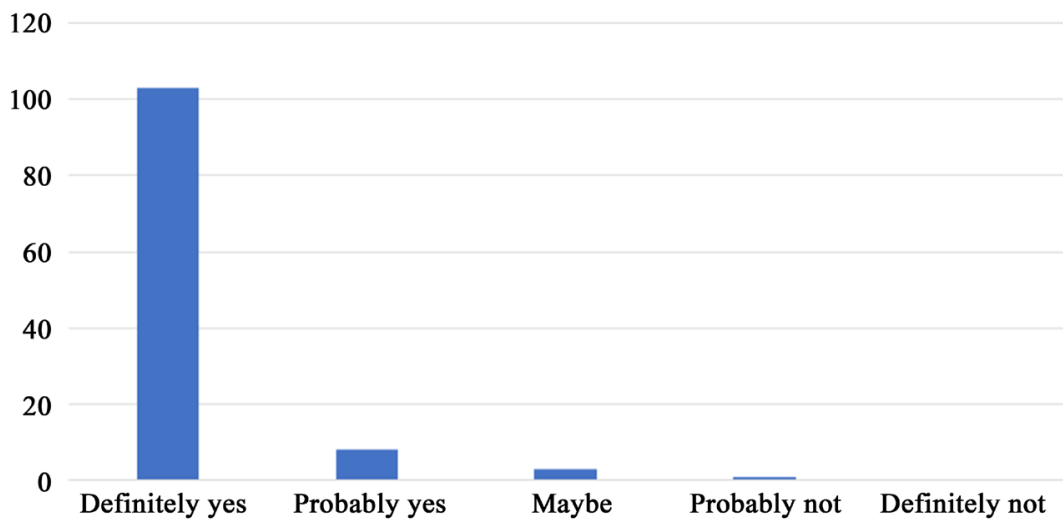

Figure 1. Employers who believe Covid-19 has affected their supply chain.

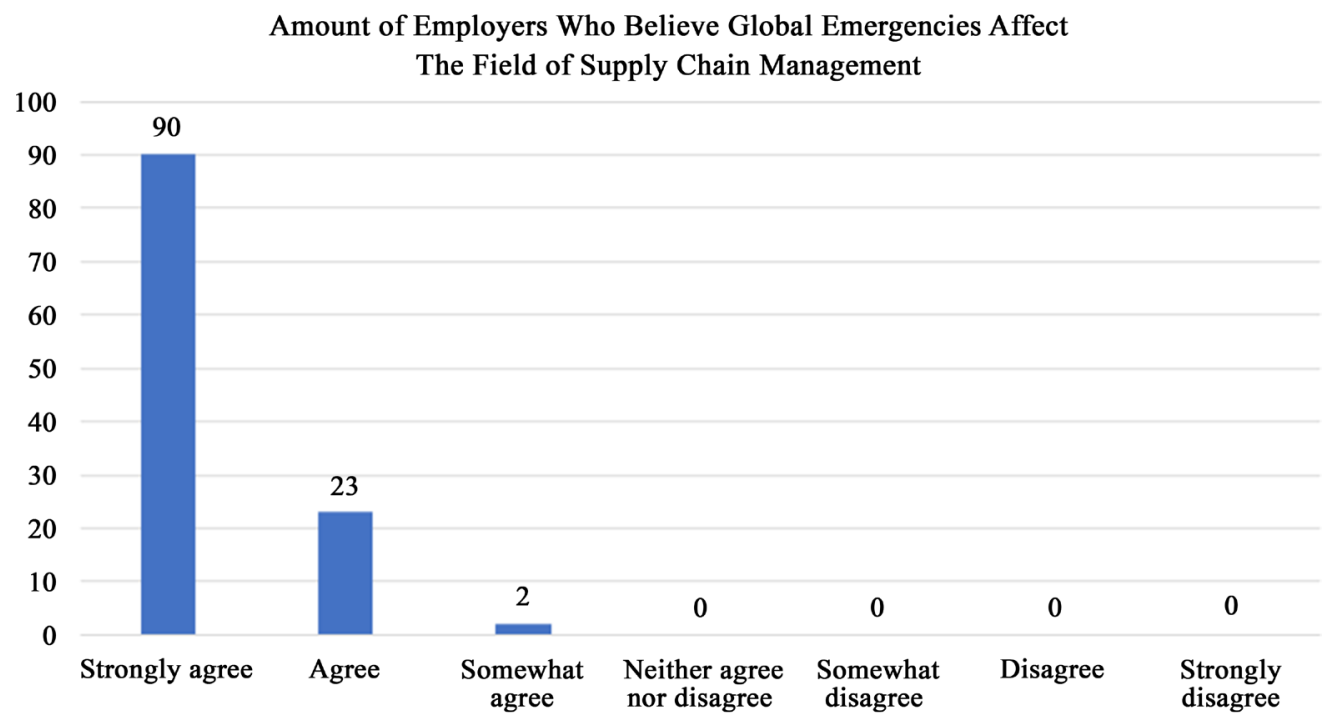

Figure 2. Employers who believe global emergencies affect the field of supply chain management. 
likely to be an effect on graduating students.

\subsection{Important Changes}

The pie chart in Figure 3 describes how many employers believe that there were significant changes within their company that graduating students should be aware of.

Based on the data found in Figure 3 it is indicated that $59 \%$ of employers believe that there were important changes implemented that graduating students should know about and $41 \%$ believe there were not. The results were quite even meaning depending on the company and industry there is about a $50 \%$ chance that as a graduating student there are some things you may need to be aware of.

There were two open ended questions asked in the survey relating to the data in Figure 3 to discover what the changes since Covid-19 were that employers believed graduating students should be prepared for. The first was "what segments of the supply chain have been most affected?" and the second was "what were the biggest changes implemented?"

It was found that all segments of the supply chain were affected in one way or another. Most prominently manufacturing, lead times, oversees suppliers shutting down, and productivity were affected. Manufacturing facilities adhering to new safety measures and many workers having shorter hours or working from home are some of the main ways they have been affected. Lead times have become unknown and extremely difficult to forecast. Many oversees suppliers have shut down making it difficult to obtain product and maintain inventory. Some companies have changed to suppliers in the U.S. or built local facilities to avoid the uncertainty of oversees suppliers. Productivity has significantly decreased due to new protocols being put in place. For instance, employees are having to work from home, hours are being cut short, and low to no inventory is available for some.

For the biggest changes implemented that students should be aware of it was

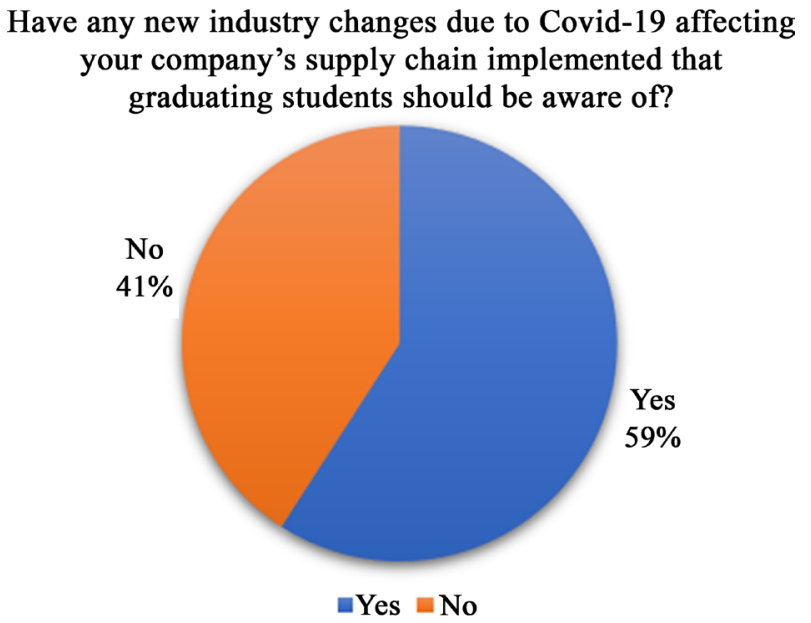

Figure 3. Employers who believe there have been significant industry changes since Covid-19 that students should be aware of. 
found that they should be prepared to get creative and work with what they have available. There are lots of new technologies and methods being put into place and it is important to keep an open mind and be ready to adapt and learn on the fly. The ability to communicate was also affected. It will now be harder to reach people when working from home instead of the warehouse or office. At times it will be important to be aggressive to get a hold of an employer or co-worker to get help and excel. Students must also be prepared to adhere to many new safety protocols and precautions.

\subsection{Hiring Rate}

Figure 4, Figure 5, and Figure 6 indicate how Covid-19 has affected hiring rates in the supply chain field. Figure 4 asks whether Covid-19 affected employers hiring of supply chain management students. Figure 5 asks whether the hiring rate increased or decreased. Figure 6 asks whether employers are looking to recruit individuals with prior supply chain expertise or if they are willing to take in new talent.

Figure 4 shows that the hiring rate of supply chain management students has in fact been affected by Covid-19 for some companies. $47 \%$ of employers noted a

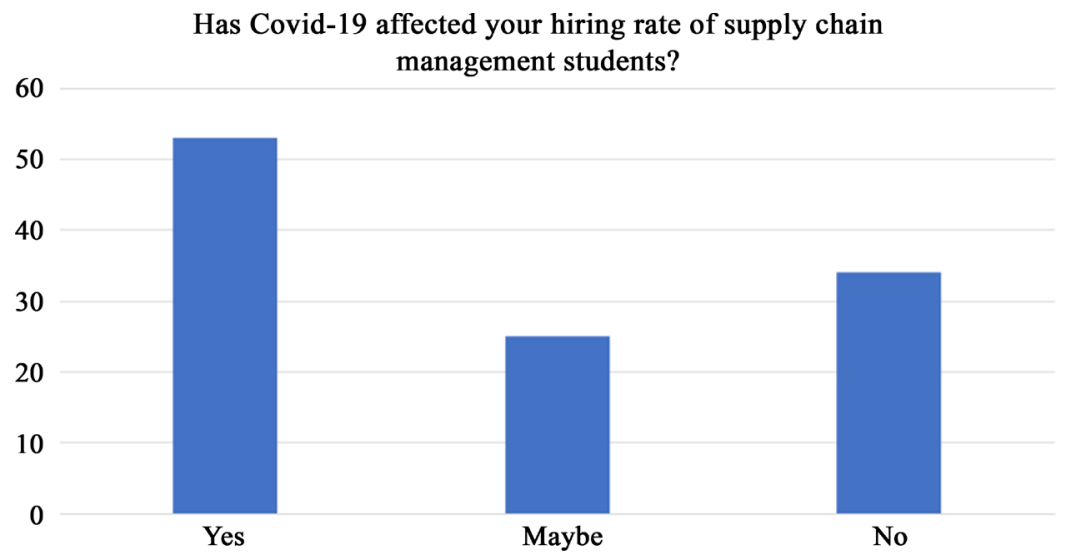

Figure 4. Covid-19's effect on the hiring rate for supply chain management students.

If your hiring rate has been affected did it increase or decrease?

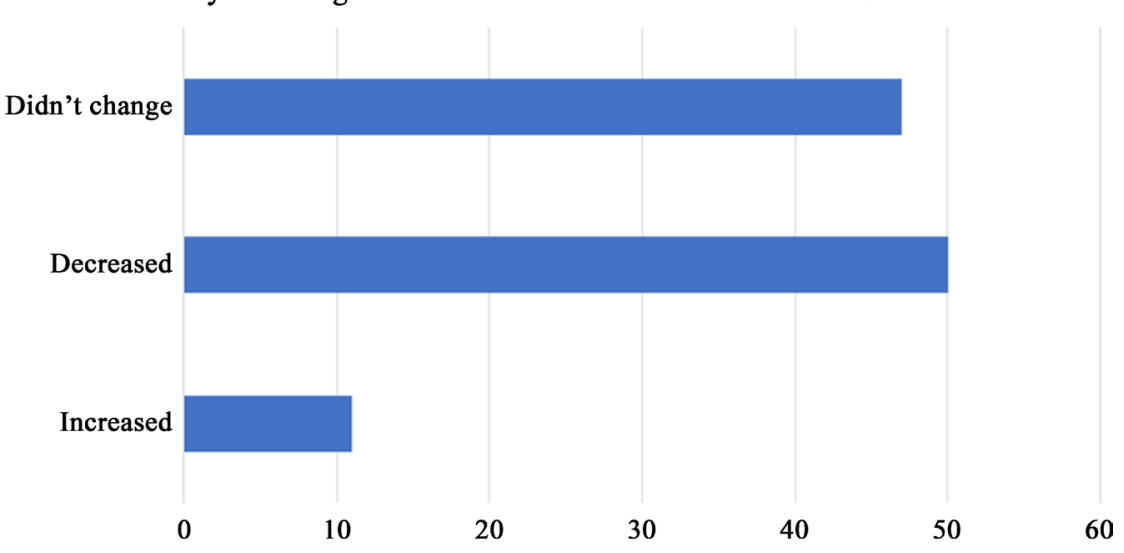

Figure 5. Increase/decrease of hiring rate for supply chain management students. 
Are you primarily looking to recruit supply chain workers with expertise or are you willing to take in new talent?

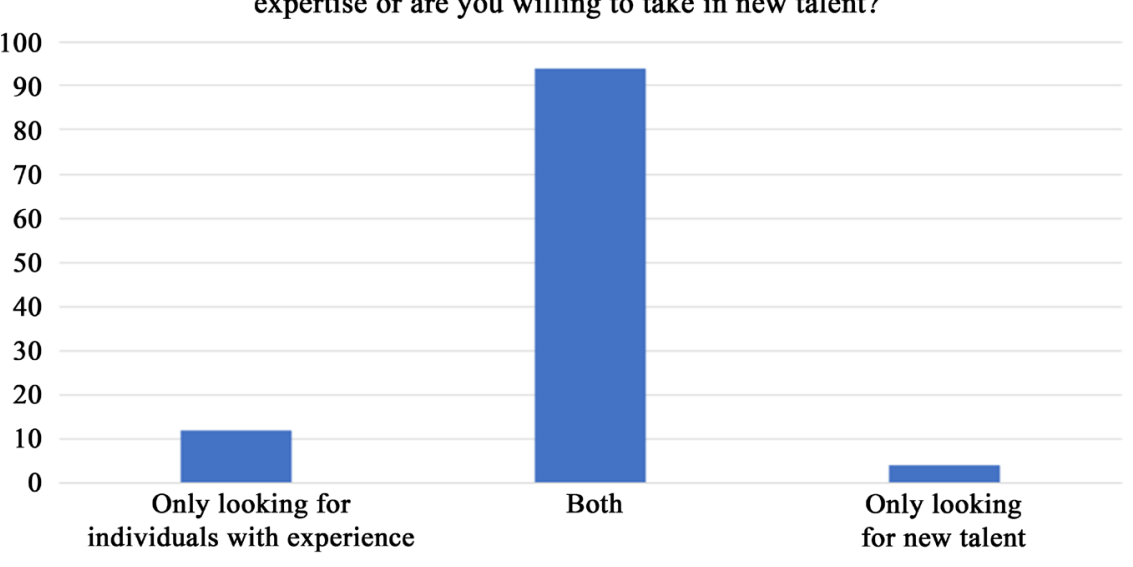

Figure 6. Expertise recruiters are looking for.

change in their hiring rates, $22 \%$ said their rates may have changed, and $31 \%$ said there has not been a change in their hiring rates.

Figure 5 shows that the hiring rate for $90 \%$ of the sample size either did not change or decreased and for $10 \%$ the hiring rate increased.

Figure 6 indicates that most employers are still open to hiring both individuals with expertise and without. $85 \%$ said they would hire both, $11 \%$ said only individuals with expertise, and $4 \%$ said that they are only looking for new talent.

The overall results of Figure 4, Figure 5, and Figure 6 indicate that depending on the industry and company there is a good chance that they either decreased their hiring or their hiring rate has yet to change. Also, the most of them are still open to hiring both newly graduated students and individuals with expertise.

\subsection{Necessary Skills}

Figure 7 investigates whether employers feel students should be informed and trained on the implications that Covid-19 has caused on the supply chain field prior to applying for an employment position.

Based on the results of Figure 7 it was found that employers do feel students should study the effects of Covid-19 on the supply chain industry. $84 \%$ of the sample size said students should be informed and only $5 \%$ said that they should not. This data indicates that it is important for students to know the changes and implications that Covid-19 has caused.

Relating to Figure 7, two open ended questions were asked about preparing students for employment during this critical time. They asked, "since the start of Covid-19 are there any skills/attributes that you would like to see in a graduating supply chain management student" and "what would 'impress' you or help a newly graduated student stand out during these critical times?".

It was found that risk management was one of the most important skills/attributes to sharpen up on as it is seen as an important asset during this period. Everything in this moment is unpredictable and it is always good to be 
Do you feel students should be informed and trained on the implications that Covid-19 has caused?

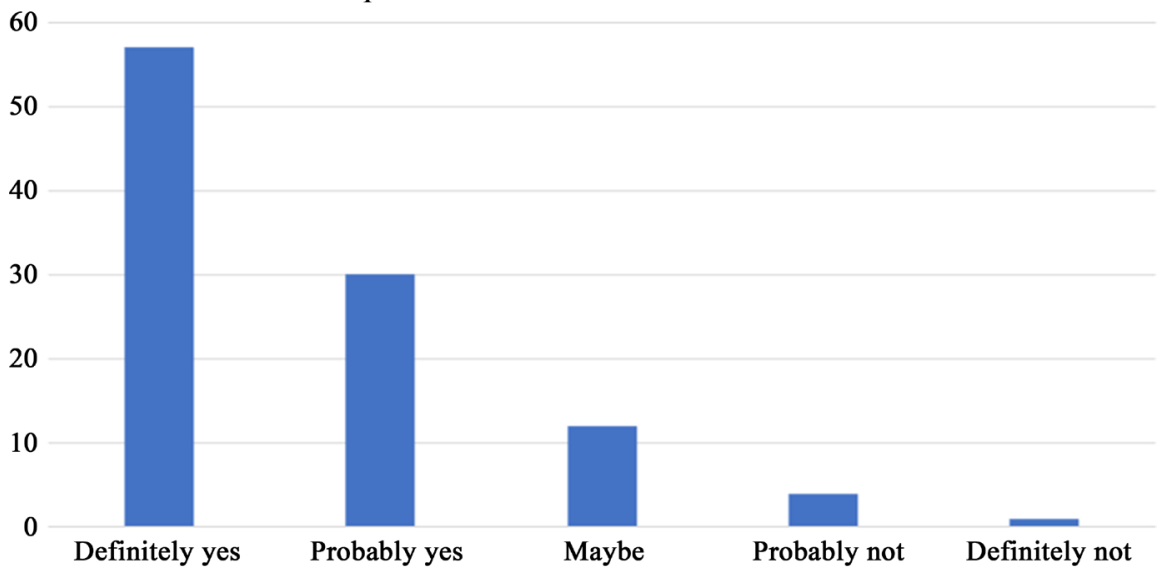

Figure 7. Employers who believe students should be trained on the implication that Covid-19 has caused within the supply chain industry.

prepared for any level of risk. Some other skills of importance include effective communication, technical skills, creativity, adaptability, critical thinking, and flexibility.

As for what would impress an employer, a positive attitude in general stood out the most. Being able to show your interest and drive to want to work for a company during challenging times is seen as very desirable. It is also important to study the company, know what they stand for and why you believe you would fit in with them. Some other attributes that stood out to employers during this time were a willingness to learn, confidence, dedication, professionalism, ERP knowledge, mental toughness, teamwork, and an awareness of global trends. Lastly, a huge factor that employers found desirable in a candidate during these critical times is to show them how you have utilized your time to keep active and work to improve yourself during the pandemic. Such as getting a job, continuing to work, getting a certification, or taking an extra class. All of those show a willingness to build and succeed during a difficult time which is a very advantageous selling point to employers.

\section{Research Implications}

It was the aim of this research project to discover how Covid-19 has affected the field of supply chain management for graduating students, how students can better prepare themselves for employment, and what would make them stand out. It was hypothesized that since global disasters disrupt supply chains that the need for new talent would increase because of their ability to help navigate issues throughout this critical time. Through data analysis it was found that global emergencies do affect supply chain management but the need for students did not increase. Although, the need for new talent did not decrease either for many companies. During this critical time, it is a worry for many students that employment options are slim. An implication of this data is that it shows finding 
employment options for supply chain students should not be as feared. Many employers are still actively looking to hire both students and individuals with expertise. Another implication is that students should be able to better pitch themselves towards employers during these times of distress by knowing what they are looking for. It is important to keep active, keep improving, and to go above and beyond. Do things that are not required such as obtaining an APICS Certification, gaining extra work experience, or taking an extra course. It is also important to be flexible, creative, and prepared to adapt to new procedures and operations as many of aspects of the industry have become unpredictable due to Covid-19.

\section{Research Limitations}

The data from this study comes from 121 participants across a range of companies and industries, but not every company and industry could be included. So, these results can be generalized over a large portion of the supply chain management field, but not over every company and industry. Each operates a bit differently and outliers will exist. Especially during the Covid-19 pandemic there are many unknown factors that come into play on how each company/industry is affected.

\section{Conclusion}

The aim of this research study was to discover how Covid-19 has affected the field of supply chain management and the students graduating from it. The data analysis showed that global emergencies do affect supply chain management and the graduating students in the field. It was hypothesized that they would affect students in a positive way by increasing the need for them. The data indicated that at this current time hiring rates did not increase. The rate instead decreased for some but did not change for many. Although the rate did not increase students still should not be as worried about a lack of employment availability as there are still many employers actively searching for new talent in the supply chain management field. In the future as uncertainties from the pandemic fade away, it is possible that hiring rates may rise higher than prior to Covid-19 as companies rebuild and increase their supply chain resiliency in case of future disaster so they do not make the same mistakes again. This research also shows that there are many ways in which students should be prepared to enter the workforce during this critical time and there are also ways in which they can stand out, remembering to actively look for opportunities to improve and be ready to get creative, flexible, and adapt to new situations during these difficult times.

\section{Conflicts of Interest}

The authors declare no conflicts of interest regarding the publication of this paper. 


\section{References}

Choi, T. Y., Bindiya, V., \& Dale, R. (2020). Coronavirus Is a Wake-Up Call for Supply Chain Management. Harvard Business Review, 1, 1-6.

Kumar, S. (2011). Managing Risks in a Relief Supply Chain in the Wake of an Adverse Event. Insight, 24, 131-157. https://doi.org/10.1057/ori.2011.4 http://dx.doi.org.libproxy.library.wmich.edu/10.1057/ori.2011.4 http://libproxy.library.wmich.edu/login?url=https://search-proquest-com.libproxy.libr ary.wmich.edu/docview/864300492?accountid=15099

Linton, T., \& Bindiya, V. (2020). Corona Virus Is Proving We Need More Resilient Supply Chains. Harvard Business Review, 1, 1-10.

Long, H. (2020). Small Business Used to Define America's Economy. The Pandemic Could Change That Forever. The Washington Post, May 12, 2020.

Morath, E. (2020). How Many U.S. Workers Have Lost Jobs During Coronavirus Pandemic? There Are Several Ways to Count. The Wall Street Journal, 1, 1-3.

Pratt, M. (2013). 5 Ways to Increase Supply Chain Performance. http://business.org/ 


\section{Appendix A: Survey}

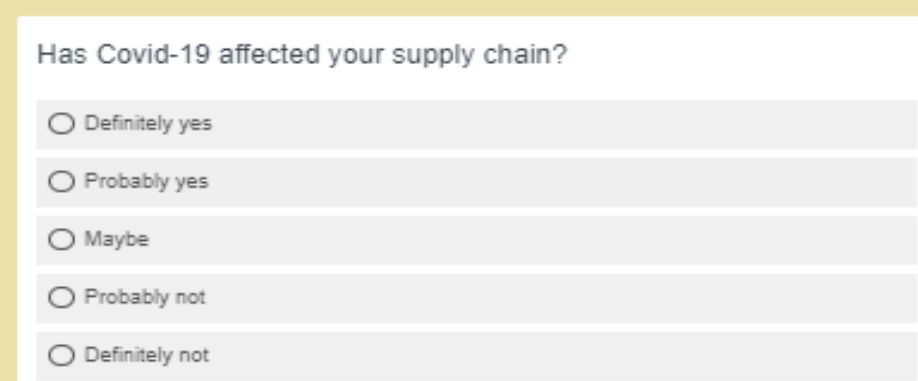

If yes to the question above, what segments of the supply chain have been most affected?

How strongly do you believe global emergencies affect the field of supply chain management?
Strongly agree
Agree
Somewhat agree
Neither agree nor disagree
Somewhat disagree
Disagree
Strongly disagree

Have any new industry changes due to Covid-19 affecting your company's supply chain been implemented that graduating students should be aware of?

$$
\begin{aligned}
& \text { OYes } \\
& \text { O No }
\end{aligned}
$$

If yes to the question above, what were the biggest changes implemented? 
Has Covid-19 affected your hiring rate of supply chain management students?
OYes
Maybe
No

If your hiring rate has been affected did it increase or decrease?
Increase
$\bigcirc$ Decrease
Didn't change

Are you primarily looking to recruit supply chain workers with expertise or are you willing to take in new talent?
Only looking for individuals with experience
Both
Only looking for new talent

Would your answer to the question above differ if asked prior to Covid-19? If yes, why? 
Since the start of Covid-19 are there any skills/attributes that you would like to see in a graduating supply chain management student during these critical times?

out during these critical times?

Do you feel students should be informed and trained on the implications that Covid-19 has caused?
Definitely yes
Probably yes
Maybe
Probably not
Definitely not

Do you have any other notes on how Covid-19 has affected your business or on how supply chain management students can be better prepared for a professional career during these critical times? 


\title{
Appendix B. Survey Short Answer Responses
}

\section{Question: What segments of the supply chain have been most affected?}

\author{
Employer \# Response: \\ Employer 1 Procurement. \\ Employer 2 Manufacturing and logistics. \\ Employer 3 I have work with 3 different (automotive) clients since Covid-19 affected our economy around 5 months ago. Their sizes \\ range from mid-market to large enterprise clients. \\ The greatest affected areas of these particular clients supply chains include the following: \\ - Management of safety stock. \\ - Supplier lead time management. \\ - Customer Accum adjustment management. \\ Most of the mid-market clients I have worked with, have also had trouble managing to keep staff on boarded to meet the \\ demands of customer order.
}

Employer 4 Our whole company but mostly Operations and transportation.

Employer 5 I personally have been furloughed for the past 6 months, only to start again this coming Monday. Industry is heavy machinery, mostly in metal stamping.

Employer 6 Oversees suppliers 100\% Hard hit us states.

Employer 7 Material availability and elimination/consolidation of intercompany roles.

Employer 8 At one point a few of our automotive customers shut down.

Employer 9 Logistics, production, on site audits, regional shutdowns, company shutdowns/bankruptcy.

Employer 10 At the start, international supply, then transitioned into sales, so pulling production. Then bullwhip effect \& not having enough inventory or production ramp up time to support.

Employer 11 Delays from domestic and international suppliers due to facility shutdowns. Transportation delays at port of origins, ports of import due to congestion caused from reduced operations.

Employer 12 The biggest effect I observed on the supply chain was extremely limited or no production for periods of time. I buy direct materials for a tier one and had to keep a very watchful eye over inventory vs. demand.

Employer 13 I supply all products relating to Covid-19 to customers. Lead-times that are unknown are hard to forecast, pricing is volatile, which can affect customers loyalty (taking advantage of a situation).

Employer 14 Every segment has been impacted service levels, capacity, inventory management, etc. It has taken a while to start to recover and we still have new product development timelines impacted due to country closures from COVID-19.

Employer 15 Inventory.

Employer 16 Our company is considered "essential" for the NA economy, with that being said if we have suppliers that are not considered "essential" and not governed by US GOV it's been a challenge to request them to turn back on. Supply Chains connected to Italy was also a challenge using a AXLE supplier as DANA for example. DANA supplies several major OEM, during Covid-19 with impacts to Italy it was critical to be first in line (this is where relationship comes into play). Covid-19 has opened out eyes to having a more dual sourcing strategy to manage risk and be agile in adjusting to risk. Issues always will happen in supply chain, its more about how fast you can adjust vs. trying to stop something that is inevitable from happening.

Employer 17 Small manufacturing facilities.

Employer 18 Operations, ensuring that we are still appropriately staffed due to associate's sensitivity while dealing with the health issues that come with COVID.

Procurement, bill of materials of what you need to run the operation has greatly increased. Primarily due to various COVID-19 initiatives which adds additional supplies.

Sourcing, due to the previous point we were having to deal suppliers we have never dealt with and forming relationships with suppliers who possibly have never worked in are line of business.

Employer 19 Substantial increase in demand has led to increased supply shortages and shortages to customers.

Employer 20 Manufacturing. 


\section{Continued}

Employer 21 Pretty much all areas, really depends on the plants capability to adjust to new safety measures and the ability if any to have employees work from home.

From floor workers to office everyone was affect with reduced work hours. Trying to adapt to new conditions.

In procurement especially many vendors had run out of stock or had nobody to fill orders for us. Many prices rose as well.

Employer 22 Smaller mom and pop companies.

Employer 23 Some suppliers with parts from Asia.

Employer 24 Supply timeliness and supplier's reliability to meet deliveries.

Employer 25 Tier 2/Tier 3 suppliers.

Employer 26 Due to work from home productivity of workers has suffered, time loss has increased an average of $10 \%-15 \%$ depending on the department.

Employer 27 All aspects to the supply chain are impacted. Not to mention the overall logistics/trucking is still stressed with the lack of manpower to move materials since 2019. I would say the tier two suppliers were impacted the most with the inability to get the raw materials for production. The biggest thing in these times is to focus on what you can control and that is cost and internal controls. Driving to gain advantage in our process efficiency and eliminate nonvalue added activities helps improve the overall impacts of the COVID impacts.

Employer 28 Part delivery from Mexico and Europe.

Employer 29 international shipments mostly from a logistics and from a production shutdown perspective.

Employer 30 planning, purchasing, manufacturing.

Employer 31 Freight cost and availability.

Employer 32 Raw Material deliveries.

Employer 33 Some of our suppliers have been closed because of a Covid-19 outbreak and some parts from Asia have been delayed.

Employer 34 Working in food, it has increased demand/strain on the network that, at times, can limit capacity and create delays in the system.

Employer 35 Electronics, components from Mexico.

Employer 36 Supply from Asia and Mexico.

Employer 37 I work in the automotive industry, and our supply chain for many parts suppliers has been impacted substantially due to plant and economic shutdowns.

Employer 38 Various aerospace suppliers in various commodities had reduced their labor force given the downtown in commercial demand resulting in long lead time for purchased items that are make-to-order.

Employer 39 Production and supplier absenteeism.

Employer 40 Lead Times.

Employer 41 Production, logistics, and sales.

Employer 42 Expending more effort regarding financial health/viability of our suppliers. Early on we saw shipping delays on some OEM equipment, but that cleared within a reasonable amount of time.

Employer 43 Logistics, Component supply, Mfg, Quality, New product introduction, Basically all of it.

Employer 44 Ryder has worked through Covid-19 for all customers that have continued production. If our customers are up and running, we are up and running. Business is delayed to an extent due to Covid-19 regulations, but freight is moving all the same.

Employer 45 Distant suppliers and suppliers supporting multiple med device/med products customers.

Employer 46 The biggest impact for us was the pause of the big 3 and their production. We move a lot of product for them so when they paused production it put a hold on our supply chain as well.

Employer 47 Working within the food solutions department of Unilever has affected the majority of business. Due to the meat shortages.

Employer 48 The biggest supply chain disruption has been in regards to available labor at all tiers. Parts are not always readily available, and many safety stocks have been depleted with no clear timeline in recovery due to labor constraints. 


\section{Continued}

Employer 49 Transportation. We went from very low demand with 1 load for every 1 truck available to 5 loads for every 1 truck available in a very short time frame (1:1 to 5:1). This caused capacity constraints as well as truckload rates to rise quickly. Another challenge is inaccurate forecasting due to uncertainty in the market.

Employer 50 International supply chain related more towards ocean transit times seeing significant increases as well as air freight costs growing in cost.

Packaging material has also had challenges, as a lot of materials have been converted for PPE demand as well as increases in E-Commerce demands.

Employer 51 Material shortages are very common due to factory shutdowns (supplier side), reduced working hours at some plants due to government restrictions, and border closures on multiple continents.

There has been a greater push to have raw materials and supplier produced parts on hand for when COVID puts restrictions on a supplier's region. Traditionally you want to keep your inventory low, but this has changed. We are producing slower, which has been helpful in reducing our finished goods inventory.

Employer 52 Demand has been cut in half. Inventory levels.

Global container shortage.

Transit time delays.

Employer 53 Lead time has been increased; logistics has tightened creating bottle neck. Overall issue is labor force has declined putting stress on manufacturing and logistics.

Employer 54 Customer demand and shifting shipping patterns. Different segments of industry have seen drastic increases/decreases in business depending on what sector they operate in. This has made long term and short-term planning and forecasting incredibly difficult on all fronts. (Work for a very large logistics/transportation company including final mile ...).

Employer 55 Supply of finished goods, transportation, distribution, construction, etc. E2E.

Employer 56 Global supply chains (China) and absenteeism.

Employer 57 Longer lead times for domestic films, and longer lead times or lack of availability for PPE and other consumable items.

Employer 58 Operations.

Employer 59 Global component manufacturing.

Employer 60 Supplier manufacturing and delivery.

Employer 61 Suppliers manufacturing capacity due to labor shortages.

Employer 62 Transactional purchasing (purchasing of "commodity type" items such as gowns and gloves) has been a challenge with international shortages of medical supplies and material used to create PPE.

Employer 63 International supply chains especially for raw goods. Expanded timelines or open ended commitment times.

Employer 64 Operations due to regional labor shortages.

Employer 65 PPE.

Employer 66 Initially it was container shortages, but now it has more to do with fruit processing plant closures due to outbreaks.

Employer 67 Manufacturing plants.

Employer 68 Logistics timing from Mexico to US is taking forever.

Employer 69 Logistics on imported goods. Difficult to get imported items in a timely fashion. I work in RVs and surprisingly COVID has caused a large spike in demand for the RV industry.

Employer 70 Transportation segment. Having employees physically load trailers and drivers to move trailers from point a to point $b$.

Employer 71 All the segments of our business have been affected since we sell oil and not too many people are travelling (Airplanes, cars etc.).

Employer 72 Warehousing, material handling, and transportation.

Employer 73 Labor workforce and Supplier manufacturing capacity (also due to labor workforce).

Employer 74 Supply has been biggest issues. COVID has caused rolling disruptions throughout China, Europe, Mexico, and the United States. With COVID, not as many people are going into work, this has caused our suppliers to not ship parts at contracted levels, in a time where demand for our products is rising above normal levels. 


\section{Continued}

Employer 75 Production shutdown, demand/supply planning, logistics network.

Employer 76 I work for an Automobile OEM in the purchasing department. We drastically changed our strategy from sourcing components out of "low-cost countries" to more localized sites in the US and Mexico. Tons of restructuring funds have been approved to help develop mfg locations more locally.

Employer 77 Suppliers being able to deliver due to the capacity and labor issues. With different states doing a varying degree of lockdowns, certain suppliers cannot meet requirements, therefore, not everything is readily available.

Employer 78 Sourcing and Transportation.

Employer 79 Inbound containers with longer lead times and supply shortage due to over sea shutdowns.

Employer 80 International shipments and suppliers shutting down temporarily or permanently.

Employer 81 Part shortages, production timeline delays, manufacturing delays, increased transportation costs.

Employer 82 For an airline, mostly from a cost reduction perspective, working with suppliers to cancel purchase orders for materials no longer required to accelerated fleet retirement as well as other cost reduction initiatives such as payment deferrals and price reduction asks.

Suppliers are also having cash flow issues, reducing the amount of inventory being held, which drives up lead times.

Employer 83 Inbound supply chain; suppliers have been having capacity issues due to closure and reduced labor pools.

Transportation costs have gone up.

Operations have slowed, especially for flexible manufacturing environments that rely on temps. People don't want to work if their unemployment is higher than their wages.

Employer 84 Our logistics freight costs have gone up because of Covid-19. We have capacity issues and finding drivers to get behind the truck because of furloughs, unemployment, and the Congress stimulus adds even more complexity. It has been rough on the transportation side of the business.

Employer 85 Customer interactions and PPE requirements.

Employer 86 basic components manufacturers and tier 1 assembly.

Employer 87 Some deliveries from our suppliers early in the pandemic.

Employer 88 USA, Hard to keep employees coming in and balancing safety precautions. Large impact on the timelines for major business process changes. Huge swings in demand from industrial customers.

Purchasing, Financing constraints internally and pressure from vendors. Impact to lead times due to shutdowns.

Production, Labor shortages/struggle to retain talent.

Distribution, Impacts to determining were to store product to be closer to end customer. Lots of "Near Shoring" considerations.

Employer 89 Increased lead times.

Employer 90 Reduced shifts at the ports causing congestion which leads to a few days delay in transit time.

Employer 91 International Shipping has been impacted the most. Smaller items that rely on air cargo have been severely limited by the reduction in passenger plane flights within the bellies of which they typically ride. Because of this Container Shipping has been slowed as the demand for containers is higher, and the capacity to load and unload the ships in port has not changed or in some cases decreased.

Employer 92 Operations/production teams at our facilities and suppliers have had to implement social distancing and health monitoring programs. Hourly labor has been harder to come by with some employees opting to stay home. Some sites have reported positive tests also impacting our workforce. Transportation rates have increased.

Employer 93 Product availability, DC capacity, Carrier capacity.

Employer 94 Tier 1 and 2 Suppliers, throughput at the ports.

Employer 95 Outbound shipments; not enough headcount in warehouses. Inbound Shipments. experiencing vendor backlog due to material availability.

Employer 96 1) Delivery delays (products, services, materials).

2) Business Travel has been cut.

3) Production (Manufacturing sector) has declined. 


\section{Continued}

Employer 97 There have been supply shortages on a global scale. Some are due to companies getting behind and others are due to companies going under due to shortage in sales.

Employer 98 Production, logistics, purchasing, basically the entire supply chain.

Employer 99 Suppliers: Financial distress and delivery issues.

Employer 100 Labor shortages in North America at all level of the supply chain. Logistic networks have also been impacted due lower demand right during the North America lockdown followed by demand increase once consumer spending picked back up.

Employer 101 Domestic, International, components, transportation.

Employer 102 Capacity has been affected the most, as our demand has continued to increase in the food and beverage industry.

Employer 103 Ability to import/export goods and materials. Reduction of flights and longer delay at borders and customs. Shortage of supplies and high demand for any pandemic PPE related supplies.

Employer 104 Acquiring raw materials.

Employer 105 Demand has changed significantly within cold chain. In the beginning of the pandemic, we were doing everything in our power to keep the grocery stores stocked due to inventory levels. We saw beef and poultry shortages due to domestic plants shutting down and cutting back on their productivity rates due to social distancing being put into place to keep employees safe. This also caused import meet prices to rise significantly. We have also seen the food service industry (restaurants) decrease but the retail industry (supermarkets) have increased signifyingly given more families eating at home. Producers were trying to redirect their processing and supply channels from restaurants to supermarkets, which have different product sizes and packaging requirements. All of this has created inventory challenges with demand levels changing. Many companies have had to adjust to consumers new habits. One of the trends we have seen increase in popularity is the direct-to-consumer meal kits.

Employer 106 All segments have been affected. Some suppliers have manpower issues due to safety issues as well the stimulus payments. Some people made more money from the stimulus payments than they make at work.

Employer 107 Logistics and Purchasing segments regarding to bringing parts in the door. We have had multiple suppliers with COVID cases that have caused delivery dates to slip.

Employer 108 Escalation of tactical actions to effectively manage business financials and supply (i.e. pushing out orders, daily forecast, inventory alignment to reduced sales, supplier moves/closures). Realignment of long-term strategies (i.e. CN sentiment, impact on volumes, capacity alignment).

Employer 109 Direct material purchases, in my personal experience. Inventories are tight due to unexpected plant closures, travel restrictions, rapid ramp-up in production levels at an OEM level. Suppliers have had a hard time keeping up.

Employer 110 Suppliers running out of product. Especially PPE related product.

Employer 111 We have been able to drive down our overall cost structure due to suppliers seeking our volume and willingness to negotiate better per price cost and payment terms.

Employer 112 Demand \& Supply.

\section{Question: What were the biggest changes implemented in the supply chain field?}

$\begin{array}{ll}\text { Employer \# } & \text { Response: } \\ \text { Employer } 1 & \text { Communicating and achieving results virtually. } \\ \text { Employer } 2 & \text { Safety Procedures. } \\ \text { Employer } 3 & \text { Listed above. If you are going into manufacturing, everything is affected. } \\ \text { Employer } 4 & \text { Overall safety protocols implemented, ranging from travel restrictions, supplier interaction, as well as intercompany interactions. } \\ \text { Employer } 5 & \text { Just the work force field itself it's different in this era. More precautions. Added lead times. } \\ \text { Employer } 6 & \text { Recently, more shift to local or North America production, to better control and understand potential impacts to supply. } \\ \text { Employer 7 } & \begin{array}{l}\text { Approach toward 100\% remote as a strategy \& broadening our talent acquisition pool. } \\ \text { The need for supply backups states side \& or better emergency planning when supply is a global risk. }\end{array}\end{array}$




\section{Continued}

Employer 8 Much more video conferencing, much less global travel across our business units. Much more communication with domestic and international supply chain partners in attempt to stay ahead of potential disruptions.

Employer 9 Maybe not a long-term change but in the short to midterm the Covid crisis resulted in reduced program volumes and program delays from OEM's. This trickled down all the way through the supply chain.

Employer 10 We look at inventory as a liability in some instances. We need to revisit stock and not rely as heavily on vendors to do so, emergency stock will be evaluated and hopefully discussed amongst leadership. MFG have consolidate parts to focus on key products to increase supply, there may be some obsolescence coming. As a distributor, i am successful if I can maintain a $99 \%$ service level. Moving customers to more common stocked parts due to Covid has made this transition easier.

Employer 11 Remote work, negotiations, plant tours, technical cost savings projects are all done electronically, which can put strain on relationships and overall fruitfulness of the business. Recommendation: get creative and the envelope is being pushed!

Employer 12 Chain of Command and understanding if you work for a good company or if you work for a GREAT company. AGCO created a chain of command that included growing trust in members from bottom to top. With myself as a supply chain leader, i can now get the attention i need as fast as possible which avoids communication barriers that were present before.

Employer 13 How to learn, train and lead your supply chain in a socially distant way.

When you're learning in college you learned the word GEMBA. Which means go and see, you quickly have to adopt how do I learn where I may not be able to physically go and see. Whether you're a buyer working to negotiate cost on an item, managing an operation, or working in logistics managing carriers. You quickly have to become creative utilizing the current resources that are available to you.

Employer 14 Additional scrutiny is placed on the safety measures, and preparedness of prospective suppliers.

Employer 15 Larger work from home role offerings, completely different technologies to aid collaboration, new methods to understand productivity. A complete revamp of our understanding of absenteeism (attendance improves while actual productivity goes down).

Employer 16 we've implemented planning outside of the ERP placing orders early giving suppliers more visibility into our upcoming demand.

Employer 17 Just working remotely and added transit time.

Employer 18 There will be changes in sanitary and safety procedures in many industries.

Employer 19 Tracking supplier absenteeism closer.

Employer 20 Tracking absenteeism.

Employer 21 I'm no longer in SC, so I can answer definitively.

Employer 22 More focus on supply chain resilience and more consideration of insourcing and local suppliers to mitigate risk.

Employer 23 Production scheduling to accommodate employee distancing policies.

Employer 24 CFO expects clear visibility into the risk associated with the supply base, what suppliers are at financial risk and what the risk to our company would be if they were no longer viable.

Employer 25 Changes in global $\mathrm{mfg}$ footprint to increase supply chain resiliency.

Employer 26 Besides the basic mask, temp checks, etc. business has continued as usual.

Employer 27 Virtual quality supplier meetings.

Employer 28 I would say the biggest thing that is being stressed in the industry now is the need to be reactive and agile in the supply chain. Being able to see issues head on and innovate to reduce the risk of a bottle neck.

Employer 29 E-commerce has experienced tremendous growth over the last 8 months.

The way and quantity in which inventory is held has changed, JIT based systems are a challenge due to increased lead times and supply constraints. Increasing levels of inventory, in particular on the PPE side is the way to go. Lower inventory is great, but you can't sell product that you don't have or can't get.

Production capacities need to be evaluated as well. With distancing measures and staffing shortages, we can't necessarily operate capacity and efficiencies at $100 \%$. This also goes back to your inventory strategies.

Risk assessment from sourcing as well as developing valuable supplier relationships. Lowest cost suppliers may be nice financially, until they can't deliver when it is needed the most. Suppliers are partners and building a long-term strategic vision now is more important than ever. 


\section{Continued}

Employer 30 Not necessarily if we are speaking about hiring's. There are no headcount reductions and we have adapted well to the new normal in my industry (Agricultural machines).

Different industries have seen different effects. Automotive has seen huge layoffs since people are suddenly driving less and amortizing their vehicles at a slower rate.

When you work at your next company, I encourage you to think about risks like what we have seen with COVID. Topics like low on hand inventory and pushing for best cashflow scenarios may really hurt a company during a pandemic or natural disaster (hurricanes, plant fires, and so on). Keep an eye on your suppliers who are critical and can only provide one-of-a-kind parts and know your second options. Ford F 150 production was stopped for a few weeks a few years ago due to a fire at a supplier. These things happen more than we want to admit.

Employer 31 Major changes on tariffs from China imports.

Employer 32 Generally speaking, there is an even stronger emphasis on optimization, best practices, methods, SOPs, and associating cost to everything that occurs within the supply chain. "Why are we doing things the way we are doing them?" There has been an emphasis, as Broncos would say, to do things "Better, Faster, and Cheaper," but organizations are realizing that they will not survive without a considerable emphasis on the aforementioned. There has also been a surge for the desire for automation. Not only is automation cost effective in the long run but there is also a resilience factor for companies who choose to invest in automation which allows them to endure through difficult times more so than they maybe would have others wise (that being said automation for automation sake is not necessarily the answer either).

Employer 33 Measures to prevent catastrophic sickness specific to pandemic. More robust redundancy plans, process, infrastructure, human assets, and others.

Employer 34 Yes, but it is a positive. The decision-making process in sourcing has shortened considerably. Before, I needed approval after approval to buy the smallest of items, now I am given the green light to make a purchase if the item meets pre-determined criteria.

Employer 35 We implemented a 7-stage plan to cover all Covid impacts.

Employer 36 Limit dependency on a just-in-time. Continue to push for more localization. Build stronger redundancies in supply base.

Employer 37 The transition from physical to digital paperwork and documentation when possible has been accelerated due to COVID-19. Tech-savvy individuals and teams have thrived.

Employer 38 Inventory on hand in the hospital is not as "Lean" as it has been. We are working to build inventory on items that are heavily used in response to the pandemic. In addition, we are working to expand our list of approved vendors and seek product domestically.

Employer 39 Carriers have changed business practices. Less routing options and no guarantees on timing.

Employer 40 More of a shift of working from home when able to. More technology such as video Skype meetings and similar to complete necessary work that would have otherwise been done in person.

Employer 41 Graduating student should prepare themselves to see a lot change. They should be open minded as they are entering the job market. Most companies are restructuring roles.

Employer 42 Working remote (for my company) has become the norm. We are not scheduled to go back until next summer, best case.

Employer 43 The emphasis on risk is higher, inventory levels are going up to provide a buffer against disruptions. Students need to know how their decisions to source in lower cost countries, and how can they mitigate some of that risk.

Employer 44 The shift towards localization, diversification, and increased risk mitigation costs.

Employer 45 No new changes necessarily, it just brings to light the resilience and agility needed for your supply chain. Understanding sourcing locations, politics of those locations, and the risk involved to do get something cheaper but not necessarily quicker need to be re-examined. As any crisis teaches us, how quickly can you adapt your supply chain when confronted with an obstacle, will set you apart from your competition. There are other lower-level factors that are effecting supply chains, but not enough space to explain.

Employer 46 Making it a point to implement dual sourcing for raw materials to mitigate supply shortages.

Employer 47 Less travel, trying to find more products domestically.

Employer 48 ESG, Environmental, Social and Governance Report for Supply Chain Risks is being reviewed and action plan being put together to implement for future supply chain risk mitigation. 


\section{Continued}

Employer 49 Be ready to grab a nice cup of coffee or beer while working at your dining room table.

Employer 50 - tight global market.

- tariff changes are still there and don't look like it's going away.

- we need to start planning long-term for Covid, not short term.

Employer 51 PPE requirements, BOLs/contractual agreements around PODs, and capacity constraints.

Employer 52 Applying practices for filling operations gaps to personnel planning based on government policies.

Employer 53 If a person can do their job remotely, that person is likely to be working from home. For a graduating student, this may represent a challenge. A lot of learning takes place at a facility and a new hire needs to be a bit aggressive with the mgr and colleagues to learn.

Employer 54 The big mindset to move supply chains out of China. MIST countries have been popular along with bringing back to USA. Industry 4.0 continues to have a large impact on automation.

WFH environments have a big impact on the overall method of doing business. No longer feasible to visit supplier sites to audit their processes as easily. Large changes to who is the point of contact (internal and external) have strained communication processes and overall business operations.

Employer 55 Less interaction with drivers, documents becoming digital rather than physical.

Employer 56 There has been a push to move more and more manufacturing capacity out of China and into other countries both in Asia and around the world. This began before COVID, but was accelerated by the pandemic. Increased activity to move manufacturing capacity to established supply lanes like India and Brazil has been accompanied by a newly developing interest in Vietnam, Laos and other similar nations with less established supply lanes and more unknowns.

Employer 57 The need to source PPE quickly and implement standard operating procedures for our employees. The shifting of corporate work from being nearly $100 \%$ on-site to completely remote. Use of MS Teams for video conferencing.

Employer 58 Telecommunication, Telecommunications have proven to be expedited during this period. I would say auto manufacturers (or manufacturers in general) have generally lacked in being able to conduct business from a remote basis. While the production floor requires the onsite presence, I have seen the while collar jobs in the back office mainly transitioned due to this.

While I feel working remotely is a Millennial push, this has expedited the process and brought to light needs for building/facilities and potential cost savings in rent for a business.

Planning, More constraints in our clients supply chain are causing them to have to plan more effectively. Longer lead times/ inability to procure items are some things I have seen.

Employer 59 Reorganization at the corporate level of functional groups (Engineering, Supply management, Marketing, etc.).

Employer 60 In general, you have to deal with more virtual work and learn how to do more with technologies.

Employer 61 The way manufacturing is done. Plants have had to figure out a way to make things socially distanced, putting extra safety precautions in place, working with fewer operators due to people being out due to COVID, figuring out ways to attract more workers due to benefits from the pandemic causing people to not want to come back to work. There is also increased timing at the borders due to COVID as well which causes more logistics issues. Also issues with material coming from overseas, huge delays due to COVID which causes more logistic issues. It is overall a massive headache to the entire supply chain.

Employer 62 More emphasis on Financial Health.

Employer 63 Be prepared for the unexpected, not only Covid, but many other issues affect supply and students need to be able to react quickly.

Employer 64 Greater focus on preferred supplier and relationships within supply chain. Want to do business with trusted suppliers with bi-lateral and win-win mindset.

Stronger segmentation focus understanding criticality of our supply chain and how to diversify and mitigate high-risk partnerships.

Employer 65 Country's ability to put export restrictions and the affect it has on those countries importing those goods.

Employer 66 The opportunity to work remotely is better than ever. Leverage the opportunity to work remotely to achieve work life balance.

Employer 67 Creating more visibility with our suppliers. For my internship in the summer of 2019, I created 3 tools that we have been using very regularly during COVID. These tools have allowed us to gain more insight into our supplier's processes and have reduced their lead times. 


\section{Continued}

Employer 68 Exponential growth in the use of Microsoft Teams, Zoom, and remote work. Reduced travel to suppliers, reduced travel from sales organization to businesses (creates potential communication and relationship building challenges which should not be understated).

Extensive use of customer as well as supplier use of Force Majeure to align demands to substantial reduction in volumes in certain long lead time industries. Understanding contractual requirements and how to work through a crisis in good faith with suppliers remotely.

Increase use of risk management measures, tracking, reporting, and actions.

Employer 69 It's too early for me to gauge any real sustaining supply chain strategy shifts specific to combating global supply/demand shocks, like a pandemic. Tactically managing the supply chain has been the biggest change that I've noticed. For example we know that supply disruptions have and will continue to happen, so there has been a focus on adequate/abundant levels of safety stock in inventories rather than a lean approach.

In general, I think the main lesson throughout the pandemic for supply chain professionals the importance of getting out in front of these major disasters, putting together concrete plans ${ }^{*}$ with ${ }^{\star}$ your supplier partners (this is key), and managing operations as best you can. Companies that were quick to react when news started coming out of China, before the virus hit US soil, have managed the crisis much better than those that waited for impacts to actually disrupt their supply chains.

Employer 70 Customers no longer being able to enter the building.

Employer 71 I believe it has reinforced our culture from cost containment standpoint along with a focus on cash generation. Cashflow never lies.

Employer 72 Job scarcity in the divisions, such as vehicle group.

Question: Would your answer change about preference on hiring new talent or individuals if asked prior to Covid-19?

\section{Employer \# Response:}

Employer 1 No.

Employer 2 No, the company I work for has stated on multiple occasions that crisis such as Covid will never stop us from looking for new talent.

Employer 3 More selective due to budgetary constraints.

Employer 4 We're looking to take on new young talent. Covid hasn't stopped this.

Employer 5 No.

Employer 6 Yes, we are reorganizing due to Covid \& it is drastically impacting all levels of the organization. Optics are considered a lot more around if you're doing layoffs, should you be bringing in new hires. Do you sacrifice your current workforce \& the engagement of your people, to focus on your talent pipeline?

Employer 7 We have found that soft skills, hard work ethic, desire to thrive are just as important as educational background. Most people can be trained to "do the job" but soft skills often make or break an employee.

Employer 8 Yes, Covid has resulted in very lean operations. We are only filling positions that are absolutely necessary right now.

Employer 9 We are small enough to where this would not really apply. I think good talent is hard to find with or without Covid.

Employer 10 Yes, because we are now looking for any and all help to move forward.

Employer 11 No.

Employer 12 Covid has slowed down the process of hire but hasn't stopped. Finding new ways to interview students has taken some time because were so use to face to face interaction. I know next year my company is looking to hire more young talent than years past and directly with WMU (if present). Seeing "layoffs" in the news can be concerning but with my company we haven't laid off a single employee globally because of Covid. Being an essential business also helps support job security long term.

Employer 13 No, my company is very specific about hiring people in supply chain with experience. It is a small group and important to hit the ground running.

Employer 14 Yes, my company has done phenomenally well due to the fact their product or platform well was equipped for the pandemic.

Employer 15 No. 


\section{Continued}

Employer 16 No.

Employer 17 Due to reduced orders and customer cancellations, it became a balancing act of staying profitable and managing talent. Hiring became much more stringent.

Employer 18 No.

Employer 19 Yes, due to Covid-19 companies are conserving cash to prep for the uncertainty this global virus has caused.

Employer 20 It would not differ.

Employer 21 No.

Employer 22 No.

Employer 23 Yes, mostly due to the rate at which the economy was growing pre-Covid. Post-Covid still has way too much uncertainty, leading to a slower hiring rate.

Employer 24 No. our team has several recent graduates. We believe that you need experienced team members to mentor new colleagues therefore we value all stages of the career path.

Employer 25 We are making sure we are only hiring people with experience, probably to ensure they won't be laid off. We can't afford to invest in new talent.

Employer 26 With more pressure to succeed NOW and navigate through the additional constraints COVID has brought, there is more of a push now to hire individuals that already have real world experience.

Employer 27 N/A. But we are on hiring freeze at this time.

Employer 28 I, personally, am not hiring, but hunting for jobs.

Employer 29 No.

Employer 30 No.

Employer 31 No.

Employer 32 No. Generally, like most companies, we have an internship program to bring graduates without any experience. We do offer entry-level roles and open to considering candidates who may not have internship experience at our company.

Employer 33 No.

Employer 34 Yes. We are hiring less due to negative business impacts resulting from Covid. But we're still hiring.

Employer 35 No.

Employer 36 Yes, I think there is a push to hiring less experienced and more personnel to work in a more virtual environment.

Employer 37 Yes, I believe if it were not for Covid we would be more heavily looking for talent to add especially around the holiday season which obviously spikes Logistics around the world. With that being said we are looking to add around 15,000 workers to help handle the holiday demand strike.

Employer 38 Yes, the business is looking for talent that can adapt fast especially now.

Employer 39 No, I feel it depends on the company. My company in particular is more focused on new talent, talent that can bring a fresh perspective to an uncertain future in the supply chain. However, experience is an added bonus.

Employer 40 No

Employer 41 No, New talent is great because there are no conceived ideas on how things should be. I would rather have someone who is smart, resourceful, and willing to do anything we throw at them. It's a fresh set of eyes and someone we can mentor and help grow.

Employer 42 Not really, we are always open minded and like new people.

Employer 43 No.

Employer 44 No depending on the candidate experience is preferred but character and personality can bypass.

Employer 45 Likely no (mostly due to the culture of the organization I work for). 


\section{Continued}

Employer 46 No different, talent and potential first.

Employer 47 My answer is the same before or after Covid-19. I am looking to bring someone in who has the ability to learn and who doesn't think they have all of the answers. I have had luck finding that profiled with experienced talent and with new talent. Be willing to learn, to take ownership of your job responsibilities, and to stay out of office drama/gossip. Do those three things and you will have success in the workplace.

Employer 48 Yes.

Employer 49 Yes, the uncertainty has strained business to the point where sustaining is the main objective.

Employer 50 No. While I'm not a hiring manager, I understand that we're always interested in a variety of SCM talent.

Employer 51 Not really. We try to find the people with the best mix of skills, drive, and affordability towards our budgets.

Employer 52 Did not differ, There are roles on my team for both new talent and experienced individuals.

Employer 53 Yes. Volume changes have placed holds on hiring as a result of order fluctuations.

Employer 54 Yes. COVID has resulted in a hiring freeze at my organization. Most of the existing employees have been forced to take multiple weeks of unpaid leaves of absence starting in Q2-2020. Prior to COVID my organization was hiring both seasoned professionals and new talent.

Employer 55 The answer would be the same.

Employer 56 It would not.

Employer 57 I don't believe there has been any changes.

Employer 58 No.

Employer 59 No.

Employer 60 Yes, our tendency has always been to recruit within our intern's pool.

Employer 61 Not at this time, our hiring of SCM talent has gone up because the demands of our products are going up and we have more people retiring.

Employer 62 Unsure. It is possible that we will need more students, but right now funds are tight.

Employer 63 No.

Employer 64 No.

Employer 65 No.

Employer 66 No.

Employer 67 No, my company for the most part, although at a reduced rate still hires entry level and experienced employees. Internship programs are still going remotely!

Employer 68 Yes, because of uncertainty in demand it's hard to determine if we'll have to operate leaner.

Employer 69 No

Employer 70 No, we are a startup. Talent needs to be either experienced players with perspective applicable to startups or staff with demonstrated hard skills to add value on projects (coding, operations mapping, contracting, etc.).

Employer 71 No.

Employer 72 No.

Employer 73 No, this has not been impacted by COVID-19. Typically, my company only recruits entry-level employees with prior work experience. However, we do offer internships to college students.

Employer 74 Yes and no, Covid obviously has tied up cash and liquidity with a lot of companies. For my company it temporarily halted the hiring but we are back to normal now. Given the background on consulting we are looking to hire in grads out of college and help them grow into the industry.

For a lot of our clients this has hurt them and has halted the hiring of new associates. For them, the answer to this would be yes. 


\section{Continued}

Employer 75 No.

Employer 76 No it would not.

Employer 77 Yes, there was a much higher demand for entry level planners and analysts with the economy being as strong as it was prior to COVID. Our business is now in the position of trying to make things work with the resources we have. The only hiring being done now is for specialists, such as individuals with more advance SAP, Business Analytics skills.

Employer 78 No.

Employer 79 Not as of now but it would depend on the industry. I believe IT purchasing is increasing due to the need for technologies in general right now. On the side of manufacturing, I think many companies have held off hiring until within the last few months where I see a major increase due to an economy that is ready to move forward despite the Covid-19 situation. I do think that industry is looking more toward experience in general as it is harder to train virtually from a distance.

Employer 80 We are not hiring at e moment.

Employer 81 Yes, given companywide hiring freeze for additional labor. Would still hire a replacement, if warranted. No, client demands experienced professionals.

Employer 82 No.

Employer 83 No.

Employer 84 No.

Employer 85 Potentially, if a large pool of experienced workers is available they could be seen as a more simple plug and play into the business during a crisis. However, this could be seen as short sighted. Often times less experienced employees (i.e. recent graduates) may come with more risk however also more upside potential for growth and a higher level of talent. This is a factor most managers take time to consider and weigh out the pros and cons of candidates.

Employer 86 Yes, until we see overall economic improvement and direction in the upcoming election cost containment and cash generation are our most important items.

Employer 87 No, we tend to look for both types of candidates.

Question: Since the start of Covid-19, are there any skills/attributes that you would like to see in a graduating supply chain management student?

\footnotetext{
Employer \# Response:

Employer 1 Creative solutions/time management/achieving results.

Employer 2 Risk Management.

Employer 3 - ERP Implementation experience.

- System Integration experience.

- Data science experience.

Employer 4 Time management since business is booming.

Employer 5 A serious attitude with a willingness to learn.

Employer 6 Ability to be an effective team member remotely and to communicate.

Employer 7 Probably would be looking for individuals who are experts on supplier sourcing to ensure a consistent supply base.

Employer 8 Covid wasn't changed what we'd expect.

Employer 9 More technological and analytics driven. There is an entire generation in the workforce that still only works off basic excel skills. Many managers are.

Employer 10 I do think of students can hone their risk management skills, it will be perceived as more of an asset during this time.

Employer 11 Technical knowledge of metals, heat treating, annealing, are in short supply. We do a lot with carbon steels, stainless steels, ductile, and cast iron. Hard to find people who truly have a good grasp on what makes metals ideal for machining.

Employer 12 Risk Mitigation: I believe Covid has companies thinking more about geographic diversification of supply. I expect to see more dual sourcing decisions in order to eliminate risk to supply if one geographic location is affected.
} 


\section{Continued}

Employer 13 Analytical ability, and ability to understand the entire supply chain process, not just the segment you maybe employed within.

Employer 14 Problem solving techniques plant experience data manipulation and analysis.

Employer 15 MENTAL TOUGHNESS. Having strong virtual interaction skills is very important at the moment. Rather than having your manager a few feet away from your desk to needing to call or text them has been difficult to adjust depending on age. The younger generation is better at adapting to change and adapting to new communication. Learning how to use Microsoft teams may be easier for a younger student than a 75-year-old buyer (and yes they can be that old, my buyer is today and will be retiring soon.

Employer 16 Data analysis/SQL is going to be more important now than ever due to the fact as companies are beginning to swap to visualization/dashboard management to indicate how they are performing every day.

Employer 17 Willingness to learn, be patient, and willing to work additional hours as needed.

Employer 18 Problem solving/crisis management.

Employer 19 Ability to adapt.

Employer 20 Ability to adapt and finding creative ways to communicate and follow up on requests. The amount of communication internally and externally that now happens through email can get lost in the mix.

Employer 21 Global impact focused.

Employer 22 No.

Employer 23 Responsiveness and having the ability to work remotely/telecommuting.

Employer 24 Agile, strong analytical acumen, ability to build strong relationships with internal and external stakeholders, high integrity.

Employer 25 Managing a remote workforce can be a challenge, understanding how to properly approach those challenges, be open, and professional in a remote setting.

Employer 26 In these times I feel it's important to have experience along with the ability to identify and challenge current processes to eliminate waste. With the workforce taking on more responsibility we need to be much more efficient.

Employer 27 Forward thinking.

Employer 28 ability to develop relationship via remote technology.

Employer 29 Effective communication abilities while using technology to their advantage.

Employer 30 Problem solving and critical thinking.

Employer 31 Outside the box thinkers.

Employer 32 Adaptability.

Employer 33 Adaptability. Willing to grow into roles outside of the job description.

Employer 34 Problem solving, quick thinking, jumping into problems.

Employer 35 Experience with the best and emerging practices in supply chain. Some can be found in the APICS SCOR phone app.

Employer 36 Ability to adapt and react in catastrophic circumstances.

Employer 37 Willingness to learn beyond their field.

Employer 38 Resiliency based thinking Critical thinking Innovative decision making Ability to perform in a fast-paced environment.

Employer 39 Experience working virtually and have good people skills.

Employer 40 Being a quick learner and not being afraid to go out on a limb and take chances is a good skill to have. There is a lot that is unknown right now in supply chains and being able to be creative and innovate is a huge skill set.

Employer 41 Critical thinking should be at the forefront of skills to know.

Employer 42 Strategic planning, ability to identify opportunity, be adaptable (work with other departments and learn what they do). 


\section{Continued}

Employer 43 The skillset has not changed; however I do think it has become more critical to be flexible, adaptable and be able to quickly think on your feet. Most supply chains are extremely busy, many operating with reduced staffing and the training has changed with more staff working remotely. Be ready for and embrace change as you enter the workforce.

Employer 44 Good pro-active communicate is more important now than ever. working remote has it's challenges, in-particular on effective communication.

Employer 45 Examples of good contingency planning.

Employer 46 Emphasis presenting what if scenarios to leadership on PowerPoint with good clear data points. Plan A, B and C etc. Example: how to handle forecasts and incoming POs now that demand has been cut in half due to COVID-19.

Employer 47 Patience and sense of urgency in problem solving.

Employer 48 Root cause analysis. Associating COST to processes, projects, programs, and being able to put together formal ROIs. How to deal with confrontation effectively and professionally (any Supply Chain/IE professional will more than likely need to "sell" ideas, processes, methods, etc. to people who are going to be less than receptive).

Employer 49 Awareness and an ability to shift quickly when things don't go the way we designed or intended. As always individuals that don't quit or break when time gets tough. Hard working people with the understanding that employment is a privilege not a given.

Employer 50 Yes, take ownership of your job responsibilities and ask advice by presenting differing options with data available if asked. These are basics for an ISM student, but they are important.

Employer 51 Keep an open mind, changes to status quo are inevitable. Textbook ideology like Cost, delivery and quality have taken on new variables that no one has experienced.

Optimism and strong work ethics are more desirable than ever.

Employer 52 Desire to learn complex processes and apply C.I. concepts. SAP, Excel, and virtual presentation skills. Relationship building ability (while working remotely).

Communication and transparency. Time management and organization. Team-oriented.

Employer 53 Be able to identify and qualify backup suppliers to ensure deliverables can continue to be met.

Employer 54 I think the same skills are critical now as they were before. Technical/systems skill is huge being able to analyze a mass amount of data to come to an informed decision. Interpersonal skills are equally as important given the diverse internal and external customer base. Someone with the potential to work under pressure and who has the general emotional intelligence to think logically and make informed decisions under pressure.

Employer 55 Contingency planning is a must.

Employer 56 Ability to train/learn effectively and quickly while working remotely.

Employer 57 More emphasis on negotiations.

Employer 58 Forecasting has been a big deal, so knowledge of that would be helpful.

Employer 59 Slight more focus in supply chain risk. Understanding what the backup suppliers or plans could be.

Employer 60 Business analytics and ability to work in virtual teams efficiently.

Employer 61 Creativity and versatility to overcome unexpected obstacles.

Employer 62 Ability to adapt quickly, dealing with ambiguity.

Employer 63 More technical skills related to Data Analysis.

Employer 64 Being able to problem solve and work in a fast pace environment.

Employer 65 Knowledge of analytics and analytics software (preferably free/Microsoft applications as large companies use those primarily on the business side (Knime, Power bi, SQL developer, etc.).

Employer 66 Soft skills and relationships are huge. You need to be able to communicate effectively with suppliers, engineering, and other stakeholders. Everyone graduating can use excel and analyze data. Can you effectively negotiate and work problems creatively with suppliers.

Employer 67 Ability to build in flexibility to your program timing and adapt is top of mind. 


\section{Continued}

Employer 68 Data-driven and understanding that nothing goes according to plan. If you can understand end-to-end supply chain dynamics, you will be a step ahead of the competition. Using that knowledge and applying the data will help keep you ahead of the curve and anticipate issues before they become bigger problems.

The other skill that will aid you is looking at situations without blinders and keeping a wide viewing range to see how decisions (big and small) impact everyone.

Employer 69 Problem-solving and adaptable. Need to be able to adapt to the every changing world we live in.

Employer 70 Critical thinking skills, calm under pressure.

Employer 71 Adaptability is really going to be the biggest attribute that I feel companies are looking for at this moment. Being able to prove and show adaptability in practice is HUGE, especially during COVID-19.

Employer 72 Project Management, Presentation Skills and Problem-Solving Skills.

Employer 73 Flexibility and patience. Training will be difficult.

Employer 74 Agility and adaptability.

Employer 75 Dedicated and hungry! We are always looking for motivated people.

Employer 76 Ability to work from home and cover new gaps created by remote working. Don't just be comfortable working from home, find out how you can create interpersonal relationships when you never are in person with your team.

Employer 77 Balancing communication; knowing when to use Email/Text/Phone is a basic requirement, but having an understanding of how to escalate issues is vital for quick resolutions.

Software adaptability being able to quickly learn a new software that is not fully documented and being able to complete the job is critical. It really sets new hires apart from skilled veterans in being able to adapt.

Employer 78 Willing to be flexible and be able to adapt to changing times.

Employer 79 The same skills that were highly sought before are still highly sought now. The skillset hasn't changed, the skill level required has gone up.

Employer 80 Communication and organization are more important than every with the remote working nature of our corporate employees. Everyone must be reliable, accountable, and able to clearly communicate with their internal and external stakeholders.

Employer 81 Technical Skills, SQL, etc.

Employer 82 sense of urgency, adaptability, situational awareness.

Employer 83 hasn't changed since pre-covid.

Employer 84 Data Analytics and Visualizations, Python and SQL for database pulls.

Employer 85 Microsoft Office (Excel, word, PowerPoint) SAP Six Sigma MBA.

Employer 86 Understand technology and be ready to utilize it on a daily basis for meetings and communication.

Employer 87 Financial acumen, solid understanding of total cost of ownership.

Employer 88 Understanding how to develop risk mitigation plans and developing a proactive vs reactive mindset would be extremely important.

Employer 89 Be flexible but firm and empathetic.

Employer 90 The ability to navigate during difficult times and stay the course. In other words, how well one can adapt.

Employer 91 Critical thinking and drive for results. Covid forced everyone to develop unique solutions not faced with BAU.

Employer 92 Ability to work remotely effectively, and use of digital tools to collaborate with team members.

Employer 93 Lean/Continuous Improvement.

Employer 94 More an attribute, resilience. Covid has added an additional layer of complexity and dynamism to the supply chain. 
Question: What would "impress" you or help a newly graduated student stand out during these critical times?

\begin{tabular}{|c|c|}
\hline Employer \# & Response: \\
\hline Employer 1 & Creative solutions. \\
\hline Employer 2 & Ability to find solutions that are not apparently obvious. \\
\hline Employer 3 & Willing to learn, eager to get out into the workforce, great time management and prioritization skills. \\
\hline Employer 4 & ERP knowledge, accounting knowledge, good attitude. \\
\hline Employer 5 & Being able to ask questions. \\
\hline Employer 6 & Candidates who could convey how they overcame critical supplier shortages, whether it was due to COVID or any other reason. \\
\hline Employer 7 & Same things as before. Hard work and a positive attitude. Relentless strive to succeed. \\
\hline Employer 8 & $\begin{array}{l}\text { Must be a "go-getter" Got to be willing to put in the time and keep the learning mindset. Self-learning is critical in today" } \\
\text { environment with everyone being stretched thin. }\end{array}$ \\
\hline
\end{tabular}

Employer 9 Individuals that know the value of team playing and the importance of having strategic back up and contingency plans.

Employer 10 Dedication, and confidence in success.

Employer 11 Continuous learning get a certification, try something new, tear down products of the company you are applying for.

Employer 12 Mental toughness, eager to learn and being passionate about your craft.

I'm solving supply chain issues that I never knew I could. I'm calling the US GOV to formulate a document to talk to Mexico to force a supplier to open up as one example. We do not have a "Playbook" for these problems and the problems are exhausting because every day is a shutdown situation that can cost millions a day. You have to love what you do, to do this every day at the intensity level it's at. Having a student that has the grit and grind to fight through these issues by my side as Batman (commodity manger) and Robin (Buyer) is what will impress me.

Employer 13 Students able to speak other languages, in particular Mandarin.

Employer 14 Demonstrating the ability to lead during the pandemic. In whatever that may be, leaders are realizing how hard it has been during this time.

Employer 15 Willing to do whatever it takes.

Employer 16 Crisis management skills in a class or from previous experience.

Employer 17 Good time management and structure.

Employer 18 I'm not sure.

Employer 19 Awareness of global trends (tariffs).

Employer 20 Positive attitude.

Employer 21 Having good communication skills outside of smart devices.

Employer 22 Professionalism, being on video, still being able to feel the positive attitude and energy even through the remote setting, someone who understands "word economy" which I know that sounds weird ... but being able to speak clearly and concisely about a topic with as few words as possible is truly a boon in this even more digital age.

Employer 23 Someone who is willing to take risk and challenge those around him to create mindful discussions. This would help create generate more ideas to Improve the overall strategy effectiveness.

Employer 24 Desire to be at the place of work if needed to support the "manufacturing" (money maker).

Employer 25 willingness to learn and ask thoughtful questions, continued involvement in leadership opportunities even during the pandemic, flexibility, and adaptability.

Employer 26 Positive attitude, experience, new ideas to help everyone work from home or working while social distancing.

Employer 27 Internships are critical.

Employer 28 Increased internal communication of the constraints impacting this industry.

Employer 29 Again, adaptability. Willing to grow into roles outside of the job description. 


\section{Continued}

Employer 30 Asking questions, being ready to work.

Employer 31 APICS certifications.

Employer 32 Cite examples of adjusting/ changing well established processes during times of panic or emergencies.

Employer 33 Their ability to multitask and learn on the job.

Employer 34 A general understand of the impact covid is having on different areas of supply chain (logistics, purchasing, mfg, etc) as well as an understand on its impact on global markets and economies.

Also, an understanding of what could change in the business world as a result of covid.

Employer 35 Creativity working in new ways, and not letting the external environment to impact their individual effort.

Employer 36 Seeing students that have been active during this time and used it to further education in the field or shown some sort of drive to improve during the lockdowns would be impressive.

Employer 37 What types of new software skills they have been trying to learn during these times?

Employer 38 When interviewing potential employees, I like to see someone that is a go-Getter and that is eager to learn and is able to identify opportunities along with proven results (senior capstone project).

Employer 39 Work experience, regardless of the industry is important. You can also stand out by highlighting your work ethic, having a positive attitude and show you have done your research about the company and role you're interviewing for.

Employer 40 Roll up your sleeves and do the dirty work. These are precedented times and there may be less opportunities than you had pre-Covid. Every opportunity you get gives it $110 \%$ because they may be fewer and farther between. Like Thomas Edison said, "Opportunity is missed by most people because it is dressed in overalls and looks like work".

Employer 41 A wide variety of working experience (Purchasing, Logistics, and Data Analytics).

Employer 42 Great excel and presentation skills.

Employer 43 Work ethic, problem solving.

Employer 44 Self-directed/driven. Always having a critical eye on terms of opportunities for improvement. Strong leadership capabilities. Strong public speaking/presentation skills. Able to associate costs/returns. All this of course on top of the skills one would expect a SC or IE professional to have.

Employer 45 Same answer.

Employer 46 Keep yourself organized and be slow to react when others are in a frenzy. Just because you work with people older than you doesn't mean that they have all the answers, or that they know how to control their emotions during tough times. Being able to do this yourself will help you shine.

Employer 47 Presentation both verbally and dress.

Employer 48 A WMU degree is impressive! Seems many strategies have shifted, I'm not sure there is anything that could have prepared businesses for what we are seeing. All changes $I \hat{a} €^{\mathrm{rw}} \mathrm{m}$ seeing are often driving additional supply chain cost and not many companies would have bought into these concepts prior to Covid.

Employer 49 Persistence to achieve personal and career goals. Strategic development of one's own skills and interests. Desire to exceed expectations. Maintaining a sustainable work-schedule and performance level (self-avoidance of burning out).

Employer 50 Some practical experience or case studies that would represent situations like this.

Employer 51 Being in the healthcare industry, a student with a supply chain internship in the healthcare industry would stand out to me especially during summer 2020. Other than Internship roles, I also see value in students who minor or dual major in CIS. Students who are genuinely interested in CIS and have a drive to continually learn technology/systems are of extreme value to me, especially in the "new normal".

Employer 52 Supply chain emergency planning and error reduction skills.

Employer 53 No difference compared to pre-COVID good experience (internships), communication skills and solid GPA.

Employer 54 Contract experience.

Employer 55 Process improvement knowledge, since covid has shown the importance of trimming down instead of acquiring new business. 
Continued

Employer 56 An understanding that change can happen very quickly and being able to react quickly is key. Understanding that safety is first, no matter what the crisis.

Employer 57 Someone with all the skills from before Covid, but maybe those who pushed on and didn't let the pandemic get in their way.

Employer 58 Previous experience and market knowledge.

Employer 59 Experience working within a supply chain during covid.

Employer 60 Their technical skills and ability to adapt to change.

Employer 61 Someone who take on challenges as opportunities to improve processes and is willing to think outside of the box during these times.

Employer 62 Knowledge of VBA, python, and SQL (Oracle, Not Microsoft access!)

Employer 63 Someone who knows how to search for and find answers while working remotely. Being outgoing and knowing who to ask for help to get things done is critical.

Employer 64 The ability to anticipate how economic and other worldly changes will impact your supply chain.

Employer 65 Having an internship that can demonstrate how they used what they learned in school to solve problems, no matter how small. Also, having an understanding with APICS certifications, be it CPIM or CSCP. This Isn't something that is needed once graduated, but having an understanding of some of the concepts will help.

Employer 66 Being aware of the bottle necks that can arise, especially with the transportation of raw materials.

Employer 67 Ability to work independently.

Employer 68 Good verbal communication and interpersonal skills. You will be working a ton with suppliers, so being outgoing and a relationship builder is necessary.

Employer 69 Finance acumen and ability to identify waste/cost in the supply chain to drive cost reductions and drive efficiencies.

Employer 70 These are trying times so perseverance and a willingness to learn and following up upon lessons learned would be a huge advantage.

Employer 71 An understanding of the changes that Covid has on the environment to the supply chain, and virtual working in an internship would be a plus.

Employer 72 Same as above.

Employer 73 Proficiency in Excel (exceptional knowledge of VBA), data analysis, and working with a team to improve process/reporting/deliverables.

Employer 74 Acting with urgency has and is even more important.

Employer 75 Communication, as always, the most critical skill in business and supply chain

Know how to be given a very vague and ambiguous task and have enough Business Acumen to understand the intended goal and what matters in accomplishing it.

Polish, overlooking the little details and small things can have a big impact. Knowing how to stay consistent with formatting and be concise in communication helps a lot. As SCM professionals often deal in parallel with legal matters, knowing what not to say can be as important as knowing what to say.

Employer 76 Being eager to learn new things and asking a lot of good questions.

Employer 77 How to tie current events/political atmosphere into potential trade deals.

Employer 78 I don't think this has changed, two keys to supply chain management: Analytics, let the facts drive the decisions, and Resourcefulness, having the acumen to find alternative means to solve problems.

Employer 79 Professionalism, prior work experience, critical thinking, and problem-solving skills. Great communication is a foundation for all these characteristics.

Employer 80 A student that can grasp the bottlenecks that the current climate presents to a supply chain.

Employer 81 A solid understanding of SAP MRP Types and how to properly use Time-Fences.

Employer 82 Knowing either Python, R, and SQL for data management and analytics.

Employer 83 APICS Certification Six Sigma Program Management (PMP). 


\section{Continued}

Employer 84 I don't feel anything has changed here other than self-starters would impress me.

Employer 85 Experience (co-op/intern).

Employer $86 \quad$ A general understanding of how a supply chain may be impacted and how do you develop risk mitigation's plans in low-risk times to prepare for uncertain futures.

Employer 87 Be open and honest, name one strength with one weakness.

Employer 88 Concrete examples of success during unprecedented times when things aren't going according to plan. The ability to stay motivated.

Employer 89 Attention to detail and well organized. SC involves loads of communication at different levels internal and external. Need to be able to gather and assimilate the important details to focus on delivery.

Employer 90 Very strong communication and computer skills.

Employer 91 Any student who has been actively involved in extracurricular activities and Internships/work studies has a leg up in my book. it shows they are committed to learn and continuously improve. Although I feel classroom is very important, I feel the practical application experience is the most important.

Question: Do you have any other notes on how Covid-19 has affected your business or on how supply chain management students can be better prepared for a professional career during these critical times?

\section{Employer \# Response:}

Employer 1 Stay up to date with industry trends.

Employer 2 You must remain flexible. Your role will temporarily shift, to take on additional responsibilities to help. Emotional intelligence is key to keep a level head during these difficult times.

Employer 3 It's going to be hard for students. I empathize \& encourage them to reach out to 2008 folks who went thru a recession. Most are successful manager level or higher individuals \& can be a great mentor support.

Employer 4 Trust your vendors, if you don't trust them, find those that you do trust. The good ones are on top of the situation and can make you successful in keeping your company stocked with product.

Employer 5 Change is going to happen and it's going to be in many forms or fashions. More online tools are being designed to help with "working from home". You need to accept that things tomorrow might not be the same as today and learn how to adjust to keep moving forward.

Employer 6 Be ready for anything and apply lessons learned and skills from previous issues to similar situations that may arise.

Employer 7 None at this time but the school should coach creativity, promote eagerness with the willingness to learn more about staying charged to deliver the objective.

Employer 8 Just be mindful of the people you interact with, with interactions being more digital, recorded, and possibly more over chats than verbal it is important to always remember that your views and culture may be different than someone else's, be mindful of how others will interpret your words. Digital meetings are almost more difficult especially with no video involved, prepare ahead of time and respect other's time, understand that if you do not, they are likely to multi-task while on the meeting and if so then you've potentially already lost them as an audience.

Employer 9 The need to properly risk mitigate existed prior to the pandemic and will exist once it is behind us. understanding the risks to supply from a geographic, political and quality perspective is necessary and requires awareness to global event. you must be willing to mitigate risk, even if prices are somewhat higher.

Employer 10 Right now, there is a lot of uncertainty in a lot of industries. We have had multiple furloughs and layoffs here at my company and there is no "end" in sight at this time. It's been a very challenging situation but being flexible and adapting to the fluidity of the situation has been key.

Employer 11 Stay patient, confident, and current on current events and continue to read and educate yourself after graduating at WMU. Good luck.

Employer 12 I think new students need to be creative to overcome challenges but also respect the severity of the challenge and how this impacting diversity in the workforce, families, age impacted groups. etc. 


\section{Continued}

Employer 13 Students need to be prepared to face unforeseen challenges and need to be able to quickly react. Being in automotive many times answers are expected quickly with a clear defined path of success.

Employer 14 The biggest change has been the drastic swing in demand in a short period of time, as well more people working remotely, which I see opportunities for working remotely becoming more of a trend in the future depending on the role. Being a team player, self-motivated and having strong work ethic continue to be key traits we look for.

Employer 15 It's stressed the importance that companies value on culture. We need good people now more than ever. Culture is showing up, communicating, caring, and doing the hard work. It can literally be the difference between making it and now during this time.

Employer 16

Not necessarily. If you have lost an internship due to COVID please still list it on your resume. The timing of this has been very bad for students who needed their summer internships. I think all hiring managers have been open minded to this.

Employer 17

Expect your workload to triple when most of the business is put on hold.

Employer 18

Don't focus on how to get "back" to how things were. Focus on how to move "forward" in the new world we live in. The world has forever changed and the people/organizations that do not change with it will not make it. Learn how to Network in a world where most communications have become virtual. Take professional certifications seriously, as well as graduate level education.

Employer 19

You have to be human in these times.

Employer 20

Covid-19 will eventually pass. Be adaptable and apply the learnings from this to weather through tough times. Make yourself a person of value by being a team player, by rising to the occasion when your organization needs people to stretch their capabilities.

Employer 21 This pandemic is an unmatched opportunity to take note of what is happening around us and respond in a way that is uncommon. People and businesses that adapt and manage change successfully will thrive. You'll create many examples for behavioral interview questions by remaining persistent and positive during this pandemic. On a career outlook note, I encourage students to remain open-minded.

Understand that career success exists in a variety of forms. I imagine the job market is challenging right now. If the dream job isn't available, look for the experience that will get you there. Also, look to work for people who will support your professional development.

Employer 22 A good understanding that issues do happen regularly, although they are difficult to predict which specific area of the supply chain could be impacted. It is important that the employing organization is committed to developing/validating multiple sources when critical. A plan needs to be regularly maintained and evaluated for readiness.

Some of this is incorporated already into things like IATF 16949 certifications if applicable.

Employer 23 Change is the only thing that is certain in this field. Plan to plan for change.

Employer 24 I feel like we are in a time where COVID-causing supply chain issues have become manageable with the amount of time that has passed. A lot of safety precautions have been put in place to keep business going, so to speak. I would say COVID has been an eye-opener to supply chains and all types of businesses that support them. It's critical that everyone thinks about other types of global disasters that could have drastic consequences on our supply chains: things like global warming repercussions, severe political conflict, possible economic recession or depression, etc. We should be understanding, if any of these things were to happen, what would be our course of action? What would be the effect on our business?

Employer 25

Companies are reluctant to hire right now due to uncertainty of when the economy will be back on track.

Employer $26 \quad$ Work on being able to be efficient outside of the office. Things like time management and routines play a huge part in how well people can perform while working from home.

Employer 27

Some companies are hiring more, and some companies are not hiring at all, you need to apply to jobs early, leverage your network and being on top of the game. If you procrastinate on the job search, you will be left behind.

Employer $28 \quad$ I am not sure there is a definite way that they can be more prepared as this was something that no one was prepared for and are still struggling to manage through.

Employer 29 Project management classes need to be used to show people how to structure time. There are operational exercises for project management which are covered in other classes, but there needs to be a required course on project management including methods for effective meetings, agendas, schedules, and working in a remote world. Too many people are using meetings as band-aids instead of structural, value-add working sessions. 


\section{Continued}

Employer $30 \quad$ Look at the three aspects:

- Business Models (P \& L, Product Mix, Partner Makeup, Supply Base Resiliency, etc.).

- Talent/Workforce Enablement (hiring/ incentives, communication).

- Technology (communication software, production hardware, analytics).

Employer 31

Business must adapt in all areas to remain in business.

Employer 32

Be ready for a less connected, and more hectic world. Depending on the field, in person work has been replaced by virtual conference rooms, calls and other socially distanced means. Because people have meetings without ever leaving their offices/homes/etc. the frequency of them has risen dramatically.

Employer 33

Be yourself, be confident, be humble, and be open to new opportunities/experiences.

Employer 34

Every industry has been impacted. The better prepared they are to understand the impacts of each industry the better they will be when entering the job market.

Employer 35 Any supply chain within North America was largely unimpacted. The largest issues my organization had with COVID-19 was large, forecasted spikes in demand from our customers coupled with regional restrictions being put in place by our suppliers country of origin with backups and shutdowns of ports.

Employer 36 We have been fortunate in my company that we have not experienced layoffs during COVID, we did have to take workweek reductions, which helped keep jobs through the worst of it.

That said, I would highly advise Supply Chain students to invest in certifications to distinguish and add value to themselves (I.E. CPIM, CSCP, CPSM).

It would also behoove a student to really invest their time into learning a programing language such as Python, R, and SQL for data management, this has been our biggest need; a resume with these skill sets will definitely catch the hiring manager's eye. I recommend these languages, as they are versatile and can be used in conjunction with just about any ERP system a company may have. This recommendation is also opposing to something like Alteryx or Automation Anywhere as, while these are phenomenal tools and also good to have experience with, they are very costly. The same functions can be done with programming languages for a fraction of the price.

Employer 37 Expect the unexpected and be proactive with suppliers to ensure you have secure supply chains.

Employer 38 Try to get as much knowledge as possible through networking, news, professional reviews/articles, etc.

Employer 39 Be ready for anything, honestly there is nothing that you can take in school that will prepare you for the unexpected in supply chain, listen, learn, and get advice from peers.

Employer $40 \quad$ Understanding the difference between process compliance and operational risk. Know when to go against the "playbook" for the betterment of the business. Key is proper documentation and accountability as to "why" you made the decision you did.

Employer 41 COVID-19 has brought many challenges to supply chain, but also brings opportunities for new graduates. Salaried employees at my company are primarily working from home. Older generations can struggle with this transition, but new grads who have strong computer skills should take this in stride. I would definitely highlight these skills in your resume and interview as this may put you ahead of others during this very unique time.

Employer 42 I think all individuals need to think about how recession/pandemic proof their company is. A lot of people don't take the time to think about the possibility of one of those events happing. When I look at the "Cold Chain" it's possibly one of the most recession/pandemic prof industry's there is. Everyone has to eat to survive. I feel that has shown in the heath of the company I work for. We have continued to grow and expand during a global pandemic. We are hiring, where other companies are laying off employees. I think that has made it easier as an employee to not have that hanging over my head. The cloud over my head right now is how can we continue to keep our employees safe so we can help serve our customers. 